\title{
PENGARUH MOTIVASI DAN LINGKUNGAN KERJA \\ TERHADAP KINERJA KARYAWAN PADA PT PERKEBUNAN NUSANTARA IV UNIT USAHA BALIMBINGAN
}

\author{
Oleh: \\ Ayu Suandani \\ S1 Manajemen \\ Darwin Lie, Marisi Butarbutar, Nana Triapnita Nainggolan
}

Abstraksi

Adapun rumusan masalah penelitian ini adalah bagaimana pengaruh motivasi dan lingkungan kerja terhadap kinerja karyawan pada PT Perkebunan Nusantara IV Unit Usaha Balimbingan. Metode penelitian yang digunakan dalam penulisan ini adalah penelitian kepustakaan dan penelitian lapangan. Populasinya adalah karyawan PT Perkebunan Nusantara IV Unit Usaha Balimbingan berjumlah 59 orang. Mengingat jumlah responden kurang dari 100 orang untuk menjawab kuesioner yang penulis sebarkan dan ketersediaan waktu penulis serta untuk keakuratan hasil penelitian. Data yang digunakan adalah data dengan cara kualitatif dan data kuantitatif, dan teknik pengumpulan data dengan cara kuesioner, wawancara dan dokumentasi. Kemudian teknik analisa data menggunakan metode deskriptif kualitatif dan metode deskriptif kuantitatif.

Hasil analisa dari regresi linier berganda yaitu $\hat{\mathrm{Y}}=8,697+0,809 \mathrm{X}_{1}+0,439 \mathrm{X}_{2}$ artinya terdapat pengaruh positif antara motivasi dan lingkungan kerja terhadap kinerja karyawan. Kekuatan hubungan ketiga variabel adalah sangat kuat, yaitu $r=0,775$. Dari koefisien determinasi dapat dijelaskan tinggi rendahnya kinerja karyawan $60 \%$, dan sisanya $40 \%$ dijelaskan oleh faktor lainnya yang tidak dibahas dalam penelitian ini. Dari hasil pengolahan dan perhitungan kuesioner, penulis mendapatkan kesimpulan bahwa motivasi dan lingkungan kerja yang diterapkan PT Perkebunan Nusantara IV Unit Usaha Balimbingan berpengaruh positif dan signifikan terhadap kinerja karyawan. Hal ini dibuktikan melalui uji hipotesis secara simultan, dimana hasil uji $\mathrm{f}_{\text {hitung }}$ $(42,034)>t_{\text {tabel }}(3,16)$ dengan taraf signifikansi $0,000<$ alpha 0,05 .

\section{Kata Kunci: Motivasi, Lingkungan Kerja, dan Kinerja Karyawan}

\section{Abstraction}

The formulation of this research problem is how the influence of motivation and work environment on employee performance at PT Perkebunan Nusantara IV Balimbingan Business Unit. The research method used in this paper is literature research and field research. Its population is employees PT Perkebunan Nusantara IV Balimbingan Business Unit amounted to 59 people. Given the number of respondents less than 100 people to answer the quetionaiere that the author distributed and the availability of time of the author and for the accuracy of the results of research. The data used is data by qualitative and quantitative data, and data collection techniques by questionnaire, interview and documentation. Then the technique of data analysis using qualitative descriptive method and quantitative descriptive method.

Result of analysis from linear regresi modestly that is $\hat{Y}=8,697+0,809 X_{1}+0,6439 X_{2}$ meaning there are positive influence between motivation and work environment on employee performance. The strength of relationship between the variables is very strength, that is $r=0,775$. From coefficient determinasi can be explainable high low employee performance $60 \%$, and the rest $40 \%$ explained by other factor not discussed in this study. From result of processing and calculation of questionnaires, the authors get the assumption that the motivation and work environment applied PT Perkebunan Nusantara IV Balimbingan Business Unit. This matter is proved by hypothesis test either simultaneously where result test the $f_{\text {hitung }}(42,034)>t_{\text {tabel }}(3,16)$ and which significant $0,000<$ alpha 0,05 .

Keywords: Motivation, Work Environment and Employee Performance

\section{A. PENDAhuluan}

\section{Latar Belakang Masalah}

Unit Usaha Balimbingan merupakan salah satu unit dari PT Nusantara IV Medan Sumatera Utara, yang bergerak dalam usaha produkssi Tandan Buah Segar (TBS) kelapa sawit. PT Perkebunan Nusantara IV Unit Usaha Balimbingan terletak di Kec. Tanah Jawa, Hatonduhan, Jorlang Hataran Kab. Simalungun Provinsi Sumatera Utara +/- 15 km dari kota Pematangsiantar. +/- $150 \mathrm{~km}$ dari ibu kota Provinsi Sumatera Utara.

Kinerja karyawan menjadi hal yang perlu diperhatikan dengan cukup serius oleh instansi, karena kinerja karyawan dengan segala aspek yang ada di dalamnya akan memberikan dampak secara langsung terhadap instansi. Kinerja karyawan merupakan suatu proses dalam mengidentifikasi, mengukur dan mengevaluasi kinerja karyawan pada suatu periode tertentu, peningkatan kinerja 
merupakan hal yang diinginkan baik dari pemberi kerja maupun para pekerja. Dimensi kinerja karyawan, yaitu kuantitas, kualitas, ketepatan waktu, kemampuan bekerjasama dan kehadiran.

Motivasi merupakan dorongan yang mempengaruhi dan mengarahkan karyawan untuk melakukan kegiatan tertentu guna mencapai tujuan secara berhasil. Dimensi motivasi meliputi: kebutuhan akan prestasi, kebutuhan akan afiliasi, kebutuhan akan kekuasaan. Pada PT Perkebunan Nusantara IV Unit Usaha Balimbingan pada kebutuhan akan prestasi memberikan kebebasan bagi karyawannya untuk mencari pengetahuan yang luas agar dapat meningkatkan prestasi kerja. Sedangkan kebutuhan akan afiliasi adalah dengan memberikan penghargaan dan tunjangan akan prestasi kerja yang tinggi. Kebutuhan akan kekuasaan yaitu memberikan kesempatan promosi agar mendorong semangat kerja karyawan.

Selain motivasi, faktor lain mempenagruhi kinerja karyawan adalah lingkungan kerja Lingkungan kerja merupakan bagian yang penting dalam meningkatkan kinerja karyawan. Lingkungan kerja pada PT Perkebunan Nusantara IV Unit Usaha Balimbingan terdiri dari lingkungan kerja fisik dan lingkungan kerja non fisik. Kondisi lingkungan kerja fisik pada PT Perkebunan Nusantara IV Unit Usaha Balimbingan masih kurang baik, hal ini terlihat dari penataan ruang kerja dan fasilitas yang mendukung pekerjaan karyawan yang belum efektif. Sedangkan pada lingkungan kerja non fisik yaitu hubungan kerjasama antara pimpinan dan bawahan, ataupun hubungan antar sesama karyawan.

\section{Rumusan Masalah}

a. Bagaimana gambaran motivasi, lingkungan kerja, dan kinerja karyawan pada PT Perkebunan Nusantara IV Unit Usaha Balimbingan.

b. Bagaimana pengaruh motivasi dan lingkungan kerja terhadap kinerja karyawan pada PT Perkebunan Nusantara IV Unit Usaha Balimbingan baik secara simultan dan parsial.

\section{Tujuan Penelitian}

a. Untuk mengetahui gambaran motivasi, lingkungan kerja, dan kinerja karyawan pada PT Perkebunan Nusantara IV Unit Usaha Balimbingan.

b. Untuk mengetahui besarnya motivasi dan lingkungan kerja terhadap kinerja karyawan pada PT Perkebunan Nusantara IV Unit Usaha Balimbingan baik secara simultan dan parsial.

\section{Metode Penelitian}

Lokasi atau tempat penelitian ini dilakukan di PT Perkebunan Nusantara IV Unit Usaha Balimbingan yang berada di Kec. Tanah Jawa, Hatonduhan, Jorlang Hatran Kab. Siamlungun. Pada penelitian ini yang menjadi populasi adalah seluruh karyawan bagian administrasi PT Perkebunan Nusantara IV Unit Usaha Balimbingan sebanyak 59 orang. Seluruh karyawan yang berjumlah 59 orang akan menjadi sampel sebagai responden untuk menjawab kuesioner yang penulis sebarkan, mengingat jumlahnya kurang dari 100 (seratus) orang dan ketersediaan waktu penulis serta untuk keakuratan hasil penelitian.

Adapun Desain penelitian yang digunakan dalam penulisan skripsi ini adalah Penelitian Kepustakaan (Library Research) dan Penelitian Lapangan (Field Research). Teknik pengumpulan data yang dilakukan penulis dalam penelitian ini adalah berupa Kuesioner, Wawancara dan Dokumentasi. Adapun jenis data yang digunakan dalam penelitian ini adalah jenis data kualitatif dan data kuantitatif. Hasil data yang diperoleh dari lapangan akan dianalisis secara deskriptif baik bersifat kualitatif dan kuantitatif.

\section{B. LANDASAN TEORI}

\section{Manajemen}

Menurut Handoko (2002:8), manajemen adalah suatu proses perencanaan, pengorganisasian, dan pengarahan dan pengendalian serta pengawasan kegiatan organisasi dan penggunaan sumber daya manusia lainnya agar tercapai tujuan organisasi. Griffin (2004:8), manajemen adalah suatu rangkaian aktivitas (termasuk perencanaan dan pengambilan keputusan, pengorganisasian, kepemimpinan dan pengendalian) yang diarahkan pada sumber-sumber daya organisasi (manusia, finansial, fisik dan informasi) untuk mencapai tujuan organisasi dengan cara yang efektif dan efisien.

Menurut Daft (2002:8), fungsi manajemen yaitu:

1) Perencanaan (planning), merupakan fungsi manajemen yang berhubungan dengan penentuan tujuan ingin diraih oleh organisasi dan penentapan tugas-tugas dan alokasi sumber daya untuk mencapai tujuan tersebut.

2) Pengorganisasian (organizing), merupakan fungsi manajemen yang berkaitan dengan penetapan dan pengelompokkan tugas-tugas ke dalam departemen dan pengalokasian sumber daya ke berbagai departemen.

3) Kepemimpinan (leading), merupakan fungsi manajemen yang melibatkan penggunaan pengaruh untuk memotivasi karyawan meraih sasaran organisasi.

4) Pengendalian (controlling), merupakan fungsi manajemen yang berhubungan dengan pemantauan aktivitas-aktivitas karyawan, menjaga organisasi agar tetap berjalan kearah pencapaian sasaran-sasarannya, dan membuat koreksi jika diperlukan

\section{Manajemen Sumber Daya Manusia}

Menurut Mondy (2008:4), manajemen sumber daya manusia adalah pemanfaatan sejumlah individu untuk mencapai tujuan-tujuan organisasi. Cara-cara yang dipraktekkan dan berhubungan dengan pemberdayaan manusia atau aspek-aspek daya manusia dari sebuah posisi manajemen termasuk perekrutan, seleksi, pelatihan, penghargaan dan penilaian. Menurut Mathis dan John (2006:3), manajemen sumber daya manusia adalah rancangan 
sistem-sistem formal dalam sebuah organisasi untuk memastikan penggunaan bakat manusia secara efektif dan efisien guna mencapai tujuan-tujuan organisasional.

Berdasarkan definisi dari beberapa ahli di atas, maka dapat disimpulkan bahwa manajemen sumber daya manusia adalah proses atau tindakan untuk merancang individu agar dari awal perekrutan, seleksi, pelatihan, penghargaan, dan penilaian agar dapat dimanfaatkan bakat yang dimiliki oleh individu tersebut untuk mencapai tujuan organisasi cara efektif dan efesien.

\section{Motivasi}

Menurut Luthans (2006:270), motivasi adalah keadaan dalam diri individu yang memunculkan, mengarahkan, dan mempertahakan perilaku. Dengan kata lain motivasi berarti dorongan terhadap seseorang agar mau melaksanakan sesuatu. Dengan adanya dorongan ini maka desakan alami untuk memuaskan kebutuhan-kebutuhan hidup dan juga merupakan kecenderungan mempertahankan hidup. Menurut Robbins \& Timothy (2006:222), motivasi adalah usaha mencapai tujuan apapun, bila dipersempit menjadi tujuan-tujuan organisasi untuk mencerminkan minat kita terhadap perilaku yang berhubungan dengan pekerjaan, jadi motivasi berpengaruh terhadap kinerja.

Berdasarkan definisi dari beberapa ahli di atas, maka dapat ditarik kesimpulan motivasi yaitu dorongan yang mempengaruhi dan mengarahkan individu untuk melakukan kegiatan dengan benar untuk mencapai tujuan organisasi.

Menurut Luthans (2006:270), jenis-jenis motivasi yaitu:

1) Motivasi Primer

Motivasi yang bersifat tidak dipelajari dan berdasarkan psikologis akan tetapi penggunaan istilah primer tidak mengimplimentasikan bahwa motif tersebut lebih diutamakan dari pada motif umum dan sekunder. Meskipun pengutamaan primer diimplimentasikan beberapa teori motivasi, tetapi ada banyak situasi dimana motif umum dan skunder lebih memotivasi dari pada motif primer.

2) Motif Umum

Motif yang tidak dapat dipelajari dan juga tidak berdasarkan psikologis tetapi penggunaannya istilah umum diimplimentasikan pada motif keinginan, manipulasi, aktivitas, dan efeksi.

3) Motivasi Sekunder

Motivasi yang dapat dipelajari dan paling relevan dengan studi perilaku organisasi. Meskipun dorongan sekunder adalah yang paling penting saat masyarakat berkembang secara ekonomi dan menjadi lebih kompleks.

\section{Lingkungan Kerja}

Menurut Nitisemito (2000:183), lingkungan kerja adalah segala sesuatu yang terdapat di sekitar tempat para pekerja yang mempengaruhi dirinya dalam menjalankan tugas pada perusahaan. Sedangkan menurut Sedarmayanti (2001:1), lingkungan kerja merupakan seluruh perlengkapan dan peralatan yang dihadapi pekerja, lingkungan sekitarnya dimana seseorang bekerja, metode kerjanya, serta pengaturan kerjanya baik sebagai perorangan maupun sebagai kelompok.

Berdasarkan definisi dari beberapa ahli di atas, maka dapat ditarik kesimpulan bahwa lingkungan kerja merupakan segala sesuatu yang ada di sekitar para karyawan yang dapat mempengaruhi diri karyawan dalam menjalankan tugas yang dibebankan oleh perusahaan

Menurut Sedarmayanti (2011:27), yang dapat mempengaruhi terbentuknya suatu kondisi lingkungan kerja dikaitkan dengan kemampuan karyawan diantaranya adalah:

1) Penerangan/Cahaya Tempat Kerja

Penerangan dalam ruangan kerja karyawan memegang peranan yang sangat penting dalam meningkatkan semangat karyawan sehingga mereka akan dapat menunjukkan hasil kerja yang baik, yang berarti bahwa penerangan tempat kerja yang cukup sangat membantu berhasilnya kegiatan-kegiatan operasional organisasi.

2) Kelembapan

Kelembapan adalah banyaknya air yang terkandung didalam udara, bisa dinyatakan dalam presentase. Kelembapan ini berhubungan atau dipengaruhi oleh temperatur udara, dan secara bersama-sama antara temperatur, kelembapan, kecepatan udara bergerak dan radiasi panas dari udara akan mempengaruhi keadaan tubuh manusia pada saat menerima atau melepas panas dari tubuhnya.

3) Tata Warna

Masalah warna dapat berpengaruh terhadap karyawan didalam melaksanakan pekerjaan, akan tetapi banyak perusahaan yang kurang memperhatikan masalah warna. Dengan begitu pengaturan hendaknya memberi fungsi, sehingga dapat meningkatkan semangat kerja karyawan. Penggunaan warna pada dinding perkantoran hendaknya memakai warna yang lembut.

4) Sirkulasi Udara

Pertukaran udara yang cukup pada ruang kerja karyawan dibutuhkan untuk kesegaran fisik dari karyawan tersebut. Suhu ruangan yang terlalu panas akan menurunkan semangat kerja karyawan dalam melaksanakan pekerjaan.

5) Kebisingan

Suara yang bunyi bisa sangat mengganggu para karyawan dalam bekerja. Suara bunyi yang mengganggu tersebut dapat merusak konsentrasi kerja karyawan sehingga kinerja karyawan bisa menjadi tidak optimal. Oleh karena itu, setiap perusahaan selalu berusaha untuk meminimalisir suara mengganggu tersebut atau paling tidak menekannya untuk memperkecil suara mengganggu tersebut.

6) Ruang gerak

Karyawan yang bekerja pada suatu perusahaan sebaiknya mendapat ruang yang cukup untuk melaksanakan pekerjaan atau tugas. Karyawan 
tidak mungkin dapat bekerja dengan tenang dan maksimal jika tempat yang tersedia tidak dapat bekerja dengan tenang dan maksimal jika tempat yang tersedia tidak dapat memberikan kenyamanan. Dengan demikian ruang gerak untuk tempat karyawan bekerja seharusnya direncanakan terlebih dahulu agar para karyawan tidak terganggu didalam melaksanakan pekerjaan. Disamping itu juga perusahaan harus dapat menghindari dari pemborosan dan menekan pengeluaran biaya yang banyak.

7) Keamanan

Rasa aman pekerja sangat berpengaruh terhadap semangat dan kinerja karyawan. Disini yang dimaksud dengan keamanan, yaitu keamanan yang dapat dimasukkan ke dalam lingkungan kerja fisik. Jika ditempat kerja tidak aman karyawan tersebut akan menjadi gelisah, tidak bisa berkonsentrasi dengan pekerjaannya serta semangat kerja karyawan tersebut akan mengalami penurunan. Oleh sebab itu seharusnya suatu organisasi terus bekerja untuk menciptakan dan mempertahankan suatu keadaan dan suasana aman tersebut sehingga karyawan merasa senang dan nyaman dalam bekerja.

8) Bau-Bau

Adanya bau-bauan disekitar tempat kerja dapat dianggap sebagai pencemaran karena dapat mengganggu konsentrasi saat bekerja.

9) Dekorasi

Dekorasi ada kaitannya dengan tata letak warna yang bagus, karena itu dekorasi tidak hanya berkaitan dengan hasil ruang kerja saja tetapi berkaitan juga dengan cara mengatur tata letak, tata warna, perlengkapan, dan lainnya untuk bekerja.

10) Musik

Menurut beberapa pakar musik yang nadanya lembut sesuai dengan suasana, waktu, dan tempat dapat membangkitkan karyawan untuk bekerja.

\section{Kinerja Karyawan}

Menurut Rivai (2004:309), kinerja merupakan perilaku yang nyata yang ditampilkan setiap orang sebagai prestasi kerja yang dihasilkan oleh karyawan sesuai dengan perannya dalam perusahaan.

Sedangkan menurut Wibowo (2011:17), kinerja memiliki makna lebih luas, bukan hanya hasil kerja namun termasuk bagaimana proses pekerjaan berlangsung. Kinerja merupakan hasil pekerjaan yang mempunyai hubungan kuat dengan tujuan perusahaan atau organisasi, keputusan konsumen, dan memberikan kontribusi ekonomi.

Berdasarkan beberapa definisi di atas, maka dapat disimpulkan bahwa kinerja merupakan hasil kerja seorang karyawan dalam melaksanakan tugas yang dibebankan. Kinerja yang optimal akan terwujud bila dapat memilih karyawan yang memiliki motivasi yang kuat yang memungkinkan mereka dapat bekerja secara baik.

Menurut Mathis dan John (2006:378), ada 5 elemen-elemen yang mempengaruhi kinerja pegawai:

1) Kuantitas dari Hasil

Yaitu jumlah hasil kerja yang dicapai dari segi tugas dan rutinitas.

2) Kualitas dari Hasil

Yaitu hasil yang dicapai dari segi ketepatan, ketelitian, dan kerapian.

3) Ketepatan Waktu dari Hasil

Yaitu kesesuaian penyelesaian pekerjaan pegawai denga tenggang waktu yang disesuaikan.

4) Kemampuan Bekerja Sama

Yaitu pegawai diharapkan mampu bekerjasama antar tim maupun rekan kerja agar tujuan perusahaan bisa tercapai.

5) Kehadiran

Yaitu agar kinerja pegawai optimal dapat dilihat dari tingkat kehadiran pegawainya.

Menurut Mangkunegara (2008:484), mengemukakan bahwa faktor kemampuan dan faktor motivasi semangat berpengaruh bagi kinerja perusahaan atau instansi yaitu:

1) Faktor Kemampuan

Secara psikologis kemampuan pegawai terdiri dari kemampuan potensi dan kemampuan reality, yang dapat diartikan bahwa pegawai yang memiliki kemampuan potensi diatas ratarata (110-120) dengan pendidikan yang memadai untuk jabatannya dan terampil dalam mengerjakan pekerjaan sehari-hari, maka ia akan lebih mudah mencapai kinerja yang diharapkan, dengan keterampilan pegawai tersebut kinerja instansi akan tercapai. Oleh karena itu, pegawai perlu ditempatkan pada pekerjaan yang sesuai dengan keahliannya sehingga pekerjaan apapun bisa dikerjakan dengan tepat waktu.

2) Faktor Motivasi

Motivasi terbentuk dari sikap seseorang pegawai dalam menghadapi situasi kerja. Motivasi merupakan kondisi yang menggerakkan diri pegawai yang terarah untuk mencapai tujuan organisasi.Sikap mental merupakan kondisi yang mendorong diri pegawai untuk berusaha mencapai prestasi kerja secara maksimal.

\section{Pengaruh Motivasi dan Lingkungan Kerja Terhadap Kinerja Karyawan}

Motivasi merupakan suatu hal yang dapat meningkatkan hasil kerja seseorang. Dengan diberikannya motivasi maka karyawan yang bekerja pada perusahaan tersebut dapat berguna dan juga membantu perusahaan untuk mencapai tujuan yang telah ditetapkannya. Menurut Robbins dan Timothy (2008:223), ada tiga hal yang dapat memotivasi seseorang untuk menghasilkan kinerja tinggi yaitu: 
kebutuhan berprestasi, kebutuhan berafiliasi, dan kebutuhan berkuasa. Setiap organisasi menginginkan agar para karyawannya mempunyai kinerja yang tinggi, sehingga tujuan organisasi dapat tercapai. Untuk dapat meningkatkan kinerja para karyawan, organisasi dapat memberi beberapa cara misalnya dengan menciptakan komunikasi organisasi yang efektif diantara karyawan dan pemberian motivasi yang sesuai dengan kebutuhan para karyawan.

Lingkungan kerja adalah segala aspek fisik kerja, psikologis kerja dan peraturan kerja yang dapat mempengaruhi kepuasan kerja dan pencapaian produktivitas sehingga menghasilkan kinerja yang tinggi bagi karyawan. Untuk dapat mempengaruhi pengaruh lingkungan kerja terhadap kinerja karyawan menurut Nitisemito (2000:183), mengatakan lingkungan kerja merupakan segala sesuatu yang ada disekitar para pekerja yang dapat mempengaruhi dirinya dalam menjalankan tugastugas yang diperintahkan. Kondisi lingkungan kerja yang baik akan memberikan pengaruh positif untuk kinerja karyawan.

Dengan demikian dapat disimpulkan bahwa terdapat hubungan positif antara motivasi dan lingkungan kerja terhadap kinerja karyawan. Adanya motivasi akan memberikan semangat dan rangsangan kepada karyawan untuk dapat bekerja dengan baik. Demikian juga adanya lingkungan kerja bagi karyawan dapat meningkatkan produktivitas kerja karyawan dan dapat tercapai tujuan organisasi

\section{PEMBAHASAN}

\section{Analisis}

\section{a. Deskriptif Kualitatif}

Analisis deskriptif dimaksudkan untuk mendapatkan gambaran atau deskripsi mengenai tanggapan dari karyawan mengenai Pengaruh motivasi dan lingkungan kerja terhadap kinerja karyawan pada PT Perkebunan Nusantara IV Unit Usaha Balimbingan. Setelah pengujian data, maka langkah selanjutnya adalah peneliti melakukan pengkajian analisis kualitatif sebagai gambaran fenomena dari variabel penelitian pada saat sekarang ini. Adapun penetapan kriteria nilai data-data jawaban dari responden tersebut dimasukkan ke dalam kelas-kelas interval, dimana penentuan intervalnya menggunakan rumus sebagai berikut: Interval kelas $=\frac{\text { Nilai Tertinggi }- \text { Nilai Terendah }}{\text { (jumlah kelas interval) }}$ $=\frac{5-1}{5}$

$=\frac{4}{5}$

$=0,8$

Dari rumus di atas, diperoleh nilai interval kelas = 0,8 , sehingga berlaku ketentuan kategori dengan hasil sebagai berikut:

Tabel 1

Nilai Interval dan Kategori Jawaban Responden.

\begin{tabular}{|c|c|}
\hline $\begin{array}{c}\text { Nilai } \\
\text { Interval }\end{array}$ & Kategori \\
\hline $1,00-1,80$ & $\begin{array}{c}\text { Sangat Tidak Baik (STB) / Sangat } \\
\text { Rendah (SR) }\end{array}$ \\
\hline
\end{tabular}

\begin{tabular}{|c|c|}
\hline $1,81-2,60$ & Tidak Baik (TB) / Rendah (R) \\
\hline $2,61-3,40$ & $\begin{array}{c}\text { Cukup Baik (CB) / Cukup Tinggi } \\
\text { (CT) }\end{array}$ \\
\hline $3,41-4,20$ & Baik (B) / Tinggi (T) \\
\hline $4,21-5,00$ & $\begin{array}{c}\text { Sangat Baik (SB) / Sangat Tinggi } \\
\text { (ST) }\end{array}$ \\
\hline
\end{tabular}

Sumber: Data diolah

\section{Gambaran Motivasi pada PT Perkebunan Nusantara IV Unit Usaha Balimbingan}

Motivasi merupakan dorongan yang dapat mempengaruhi dan mengarahkan karyawan untuk melakukan kegiatan tertentu guna mencapai tujuan secara berhasil. Semakin besar motivasi yang diberikan kepada karyawan tersebut maka semakin tinggi tingkat kepuasan kerjanya. Pada PT Perkebunan Nusantara IV Unit Usaha Balimbingan pemberian motivasi untuk meningkatkan kinerja karyawan yaitu dengan menggunakan tiga dimensi antara lain kebutuhan akan prestasi, yaitu mendorong seseorang untuk mengembangkan kreatifitas dan mengarahkan semua kemampuan serta energi yang dimilikinya demi mencapai prestasi kerja yang maksimal, penerapan yang dilakukan dengan memberikan kebebasan untuk dapat memperoleh pengetahuan guna keberhasilan prestasi kerja yang maksimal.

Kebutuhan akan afiliasi, yaitu kebutuhan akan diterima oleh orang lain dan dihargai atas prestasi kerja, dalam hal ini PT perkebunan Nusantara IV Unit Usaha Balimbingan untuk dapat menerapkannya apresiasi atau penghargaan kepada karyawan atas keberhasilan atas pekerjaan yang telah diselesaikannya, serta kebutuhan akan kekuasaan yaitu kebutuhan akan suatu jabatan, penerapan yang dilakukan seperti memberikan kesempatan promosi jabatan agar mendorong semangat kerja dari karyawan.

Berdasarkan hasil analisis deskriptif kualitatif mengenai motivasi dari dimensi kebutuhan akan prestasi, kebutuhan akan afiliasi, dan kebutuhan akan kekuasaan mendapat nilai rata-rata keseluruhan sebesar 4,13 dengan kriteria jawaban baik. Kemudian nilai rata-rata tertinggi sebesar 4,79 untuk dimensi kebutuhan akan afiliasi pada indikator keefektifan kerja yang dilakukan dengan bekerjasama bersama rekan kerja. Sedangkan nilai rata-rata terendah sebesar 3,39 untuk dimensi kebutuhan akan kekuasaan pada indikator usaha dalam menghadapi tantangan pekerjaan untuk meraih jabatan tertentu. Perkebunan Nusantara IV Unit Usaha Balimbingan

Lingkungan Kerja adalah salah satu faktor yang sangat penting bagi karyawan dan perusahaan.Lingkungan kerja harus dikelola dengan baik agar dapat memaksimalkan produktivitas karyawan.Perusahaan harus mengontrol para karyawannya agar selalu menjaga kebersihan lingkungan kerja agar tercipta suasana kerja yang 
nyaman dan aman.Karena kelancaran aktivitas karyawan, sangat ditentukan oleh lingkungan kerja.

Terdapat dua jenis lingkungan kerja pada PT Perkebunan Nusantara IV Unit Usaha Balimbingan yaitu lingkungan kerja fisik dan lingkungan kerja non fisik. Yang termasuk dalam lingkungan kerja fisik pada PT Perkebunan Nusantara IV Unit Usaha Balimbingan adalah pusat kerja, kursi dan meja yang masih layak pakai, dan kebersihan ruangan. Sedangkan yang termasuk dalam lingkungan kerja non fisik pada PT Perkebunan Nusantara IV Unit Usaha Balimbingan adalah hubungan kerjasama pimpinan dan bawahan atau sesama rekan kerja serta hubungan komunikasi antara Kepala Tata Usaha dengan sesama karyawan, dapat mengimbangi kondisi fisik kerja yang nyaman sehingga kinerja karyawan dalam organisasi dapat tercapai

Berdasarkan hasil analisis deskriptif kualitatif mengenai lingkungan kerja dari dimensi lingkungan kerja fisik dan lingkungan kerja non fisik mendapat nilai rata-rata keseluruhan sebesar 3,92 dengan kriteria jawaban baik. Kemudian nilai rata-rata tertinggi sebesar 4,35 dengan jawaban sangat baik untuk dimensi lingkungan kerja fisik dengan indikator kebersihan ruang kerja dalam menjalankan tugas. Sedangkan nilai rata-rata terendah sebesar 3,39 dengan kriteria jawaban cukup baik untuk dimensi lingkungan kerja fisik, dengan indikator tingkat kebisingan di tempat kerja.

\section{Kinerja Karyawan pada PT Perkebunan} Nusantara IV Unit Usaha Balimbingan

Kinerja merupakan salah satu hal penting dalam penilaian perusahaan karena sangat menentukan keberhasilan suatu organisasi apabila kinerja karyawan dalam sebuah perusahaan sudah baik, maka tujuan perusahaan dapat dengan mudah tercapai. Pada PT Perkebunan Nusantara IV Unit Usaha Balimbingan ada beberapa dimensi kinerja karyawan yaitu Kuantitas dari hasil kerja, yaitu jumlah kerja yang dilakukan dalam satu periode waktu yang ditentukan. Kualitas dari hasil kerja, yaitu kualitas kerja yang dicapai berdasarkan syaratsyarat kesesuaiannya. Dan pada dimensi ketepatan waktu, yaitu kesesuaian penyelesaian pekerjaan karyawan dengan tenggang waktu yang diseesuaikan. Untuk dimensi Kerjasama, yaitu karyawan diharapkan mampu bekerjasama antar tim maupun rekan kerja agar tujuan perusahaan bisa tercapai. Sedangkan pada dimensi kehadiran, yaitu agar kinerja karyawan optimal dapat dilihat dari tingkat kehadiran karyawannya.

Berdasarkan hasil analisis deskriptif kualitatif mengenai kinerja karyawan dari dimensi kuantitas, kualitas, ketepatan waktu, kemampuan bekerjasama, dan kehadiran memperoleh nilai rata-rata keseluruhan sebesar 4,08 dengan kriteria baik. Pada rata-rata tertinggi sebesar 4,29 dengan kriteria sangat baik terdapat pada dimensi kuantitas, dengan indikator hasil kerja yang diperoleh. Sedangkan ratarata terendah sebesar 3,36 dengan kriteria cukup baik terdapat pada dimensi kehadiran, dengan indikator tingkat kehadiran karyawan selama bekerja.

\section{b. Deskriptif Kuantitatif}

\section{1) Analisa Regresi Linear Berganda}

Fungsi dari analisis regresi adalah untuk melihat pengaruh yang terjadi di antara ketiga variabel. Selain itu analisis regresi juga berfungsi sebagai penunjuk arah hubungan yang terjadi antara variabel dependen dan variabel indenpenden. Untuk melihat apakah ada pengaruh motivasi dan lingkungan kerja terhadap kinerja karyawan pada PT Perkebunan Nusantara IV Unit Usaha Balimbingan digunakan analisis regresi linear berganda.

Tabel 17

Analisis Regresi Linier Berganda

\begin{tabular}{|l|c|c|c|}
\hline \multirow{2}{*}{ Model } & \multicolumn{2}{|c|}{} & $\begin{array}{c}\text { Standardiz } \\
\text { ed } \\
\text { Unstandardized } \\
\text { Coefficient } \\
\text { Coefficients }\end{array}$ \\
\cline { 2 - 4 } & $\boldsymbol{B}$ & $\begin{array}{c}\text { Std. } \\
\text { Error }\end{array}$ & Beta \\
\hline 1 (Constant) & $\mathbf{8 . 6 9 7}$ & 5.890 & \\
Motivasi & $\mathbf{8 0 9}$ & .188 & .449 \\
Lingkungan Kerja & $\mathbf{. 4 3 9}$ & .108 & .422 \\
\hline
\end{tabular}

a. Dependent Variabel: Kinerja Karyawan

Sumber: hasil pengolahan data menggunakan spss versi 21.

Berdasarkan hasil penelitian tabel 17, maka dapat disusun persamaan regresi sebagai berikut: $\hat{Y}=$ $8,697+0,809 \mathrm{X} 1+0,439 \mathrm{X} 2$, artinya bahwa terdapat pengaruh positif antara variabel bebas motivasi $\left(\mathrm{X}_{1}\right)$ dan lingkungan kerja $\left(\mathrm{X}_{2}\right)$ terhadap kinerja karyawan (Y) pada PT Perkebunan Nusantara IV Unit Usaha Balimbingan.

\section{2) Korelasi dan Koefisien Determinasi}

Untuk menghitung kekuatan hubungan motivasi, lingkungan kerja dan kinerja karyawan, dilakukan melalui analisis korelasi dan koefisien determinasi dengan rumus sebagai berikut:

Tabel 18

Korelasi dan Koefisien Determinasi

\begin{tabular}{|c|c|r|r|r|}
\hline $\begin{array}{c}\text { Mode } \\
1\end{array}$ & $\mathbf{R}$ & $\begin{array}{c}\boldsymbol{R} \\
\text { Square }\end{array}$ & $\begin{array}{c}\text { Adjusted } R \\
\text { Square }\end{array}$ & $\begin{array}{c}\text { Std. Error of the } \\
\text { Estimate }\end{array}$ \\
\hline 1 & $\begin{array}{r}\mathbf{7 7 5} \\
\mathrm{a}\end{array}$ & $\mathbf{. 6 0 0}$ & .586 & 4.607 \\
\hline
\end{tabular}

a. Predictors: (Constant), Motivasi, Lingkungan Kerja

b. Dependent Variabel: Kinerja Karyawan

Sumber: hasil pengolahan data menggunakan spss versi 21.

Berdasarkan hasil penelitian pada tabel 18, diperoleh $r$ sebesar 0,775 , yang artinya terdapat hubungan yang kuat dan positif antara motivasi, lingkungan kerja, dengan kinerja karyawan pada PT Perkebunan Nusantara IV Unit Usaha Balimbingan. Berdasarkan tabel 18 selanjutnya diperoleh nilai koefisien determinasi ( $\mathrm{R}$ Square $)=0,600$, artinya 
tinggi rendahnya kinerja karyawan (Y) di PT Perkebunan Nusantara IV Unit Usaha Balimbingan sebesar 60\% dapat dijelaskan oleh Motivasi (X1) dan Lingkungan Kerja (X2), sedangkan sisanya $40 \%$ dipengaruhi oleh faktor lain seperti budaya organisasi, disiplin kerja, pengembangan karir, pelatihan, kepuasan kerja, kompensasi dan faktor lain yang tidak dibahas dalam penelitian ini.

\section{3) Uji Hipotesis}

a) Uji Simultan (Uji F)

Uji F digunakan untuk mengetahui apakah variabel bebas (motivasi dan lingkungan kerja) berpengaruh terhadap variabel terikat (kinerja karyawan) secara bersama-sama atau simultan. Yaitu dilakukan untuk menentukan diterima atau ditolaknya hipotesis. Jika tingkat signifikan dibawah $5 \%$ atau $\mathrm{F}_{\text {hitung }}>\mathrm{F}_{\text {tabel }}$ maka $\mathrm{H}_{0}$ ditolak.

Tabel 19

Perkiraan Nilai F hitung

\begin{tabular}{|ll|r|r|r|r|r|}
\hline Model & $\begin{array}{c}\text { Sum of } \\
\text { Squares }\end{array}$ & df & $\begin{array}{c}\text { Mean } \\
\text { Square }\end{array}$ & F & Sig. \\
\hline 1 Regressio & 1784.49 & 2 & 892.24 & $\mathbf{4 2 . 0 3}$ & $\mathbf{. 0 0 0}$ \\
& $n$ & 6 & 2 & 8 & $\mathbf{4}$ & $\mathbf{b}$ \\
& Residual & 1188.69 & 5 & 21.227 & & \\
& 1 & 9 & & & \\
Total & 2973.18 & 5 & & & \\
& 6 & 8 & & & \\
\hline
\end{tabular}

a. Dependent Variabel: Kinerja Karyawan

b. Predictors: (Constant), Motivasi, Lingkungan Kerja

Sumber: hasil pengolahan data dengan SPSS versi 21.

Berdasarkan table 19 di atas diperoleh hasil $\mathrm{f}_{\text {hitung }}$ dengan $\mathrm{df}=\mathrm{n}-\mathrm{k}-1 \quad(59-2-1=56)$ sebesar 42,034, sedangkan $\mathrm{f}_{\text {tabel }}(0,05 ; 2$ vs 59$)$ sebesar 3,16 atau dengan signifikansi $0,000<$ alpha 0,05 , maka $\mathrm{H}_{0}$ ditolak, artinya motivasi dan lingkungan kerja berpengaruh positif dan signifikan terhadap kinerja karyawan pada PT Perkebunan Nusantara IV Unit Usaha Balimbingan

\section{b) Uji Parsial (Uji t)}

Untuk menghasilkan suatu kesimpulan yang valid, maka harus dilakukan uji hipotesis. Pengujian ini dilakukan untuk menentukan diterima atau ditolaknya hipotesis, pengujian hipotesis dilakukan untuk mengetahui apakah variabel motivasi dan lingkungan kerja yang diuji berpengaruh terhadap kinerja karyawan. Jika tingkat signifikansi dibawah $5 \%$ atau $\mathrm{t}_{\text {hitung }}>\mathrm{t}_{\text {tabel }}$ maka $\mathrm{H}_{0}$ ditolak.

Tabel 20

Perkiraan Nilai thitung

\begin{tabular}{|ll|c|c|}
\hline \multicolumn{2}{|c|}{ Model } & $\mathbf{t}$ & Sig. \\
\hline 1 (Constant) & 1.477 & .145 \\
& Motivasi & $\mathbf{4 . 3 0 9}$ & $\mathbf{. 0 0 0}$ \\
\multicolumn{2}{|c|}{ Lingkungan Kerja } & $\mathbf{4 . 0 5 1}$ & $\mathbf{. 0 0 0}$ \\
\hline
\end{tabular}

a. Dependent Variabel: Kinerja Karyawan
Sumber: hasil pengolahan data dengan SPSS versi 21.

Dari tabel 20 di atas diperoleh nilai $t_{\text {hitung }}$ pada variabel X1 (motivasi) sebesar 4,309 > $\mathrm{t}_{\text {tabel }}$ dengan $\mathrm{df}=\mathrm{n}-\mathrm{k}-1(59-2-1=56)$ sebesar 2,003 atau taraf signifikansi $0,000<$ alpha 0,05 , maka $\mathrm{H}_{0}$ dtolak, artinya motivasi berpengaruh positif dan signifikan terhadap kinerja karyawan pada PT Perkebunan Nusantara IV Unit Usaha Balimbingan. Kemudian nilai $t_{\text {hitung }}$ pada variabel X2 (lingkungan kerja) sebesar 4,051 $>\mathrm{t}_{\text {tabel }}$ dengan $\mathrm{df}$ $=\mathrm{n}-\mathrm{k}-1 \quad(59-2-1=56)$ sebesar 2,003 atau taraf signifikansi $0,000<$ alpha 0,05 , maka $\mathrm{H}_{0}$ ditolak, artinya lingkungan kerja berpengaruh positif dan signifikan terhadap kinerja karyawan pada PT Perkebunan Nusantara IV Unit Usaha Balimbingan.

\section{Evaluas}

a. Motivasi Pada PT Perkebunan Nusantara IV Unit Usaha Balimbingan

Berdasarkan hasil rekapitulasi penelitian, maka diperoleh hasil penelitian yang menyatakan bahwa motivasi yang terdapat pada PT Perkebunan Nusantara IV Unit Usaha Balimbingan memiliki rata-rata secara keseluruhan sebesar 4,13 dengan kriteria jawaban baik. Sedangkan pada dimensi kebutuhan akan kekuasaan dengan indikator usaha dalam menghadapi tantangan pekerjaan untuk meraih jabatan tertentu yang memperoleh rata-rata 3,39 dengan kriteria cukup baik, hal ini disebabkan semua tugas yang diberikan perusahaan terkadang selalu tidak tepat waktu dalam menyelesaikan tugasnya.

Pada dimensi pada dimensi kebutuhan akan prestasi pada indikator usaha dalam mencapai pengetahuan untuk dapat mencari prestasi kerja diperoleh nilai rata-rata 4,08 dengan kriteria jawaban baik, hal ini disebabkan karyawan diberi kebebasan untuk mengembangkan ilmunya dan mengaplikasikan disaat karyawan bekerja. Pada dimensi kebutuhan akan afiliasi pada indikator tentang inisiatif karyawan dalam suatu pekerjaan dihargai oleh pemimpin berada pada nilai rata-rata 4,00 dengan kriteria jawaban baik, hal ini disebabkan setiap inisiatif yang dilakukan karyawan menjadi bahan pertimbangan pimpinan dalam memberikan penghargaan dan menilai potensi diri karyawan.

Dari evaluasi motivasi di atas dapat diambil kesimpulan jika semua hal-hal di atas sudah berada pada kriteria jawaban baik. Sehingga dapat disimpulkan bahwa motivasi yang ada pada karyawan PT Perkebunan Nusantara IV Unit Usaha Balimbingan telah mencapai tujuan organisasi secara berhasil. Namun masih ada indikator yang belum optimal, untuk itu pemimpin perusahaan sebaiknya meningkatkan motivasi bagi karyawan yang berprestasi dengan cara memberi penghargaan atas hasil kerjanya agar karyawan bersemangat dalam bekerja. 


\section{b. Lingkungan Kerja Pada PT Perkebunan Nusantara IV Unit Usaha Balimbingan}

Berdasarkan hasil rekapitulasi penelitian, maka diperoleh hasil penelitian yang menyatakan lingkungan kerja yang terdapat pada PT Perkebunan Nusantara IV Unit Usaha Balimbingan memiliki rata-rata secara keseluruhan sebesar 3,92 dengan kriteria jawaban baik. Sedangkan pada indikator yang memiliki nilai dibawah rata-rata terdapat pada dimensi lingkungan kerja fisik dengan indikator tingkat kebisingan di tempat kerja memiliki rata-rata 3,39 dengan kriteria cukup baik, meskipun masih berada di kriteria cukup baik, namun angka ini merupakan nilai terendah dari keseluruhan dimensi lingkungan kerja fisik , Cara untuk mengatasi hal tersebut adalah perusahaan sebaiknya menyediakan fasilitas yang bagus atau layak agar suasana kerja terasa aman dan nyaman.

Pada dimensi lingkungan kerja fisik pada indikator kenyamanan di tempat kerja yang berada pada nilai rata-rata 3,84 dengan kriteria jawaban baik, hal ini disebabkan dengan ruangan yang bersih dan fasilitas yang memadai maka karyawan akan nyaman dan betah saat melakukan pekerjaan, sehingga semua tugas yang diberikan dari pimpinan akan terselesaikan dengan baik dan tujuan perusahaan akan tercapai. Pada dimensi lingkungan kerja non fisik pada indikator hubungan kerjasama antara sesama karyawan berada pada nilai rata-rata 3,88 dengna kriteria jawaban baik. Cara untuk mengatasi hal tersebut sebaiknya karyawan dengan karyawan lain selalu bekerjasama dalam mengambil keputusan maupun dalam menyelesaikan suatu pekerjaan.

Dari evaluasi lingkungan kerja di atas dapat diambil kesimpulan jika semua hal-hal diatas sudah berada pada kriteria jawaban baik. Sehingga dapat disimpulkan bahwa lingkungan kerja harus dikelola dengan baik agar dapat memaksimalkan produktivitas karyawan. Namun perusahaan dapat meningkatkan indikator-indikator tersebut dengan lebih memperhatikan kondisi lingkungan kerja karyawan seperti melakukan penataan kembali penempatan meja dan kursi karyawan.

\section{c. Kinerja Karyawan Pada PT Perkebunan Nusantara IV Unit Usaha Balimbingan}

Berdasarkan hasil rekapitulasi penelitian, maka diperoleh hasil penelitian yang menyatakan bahwa kinerja karyawan yang terdapat pada PT Perkebunan Nusantara IV Unit Usaha Balimbingan memiliki rata-rata secara keseluruhan sebesar 4,08 dengan kriteria jawaban baik. Namun ada beberapa aspek walaupun dinilai baik tetapi masih terdapat nilai yang berada dibawah rata-rata dari indikator lainnya.

Dimensi pertama yang nilainya berada dibawah rata-rata terdapat pada dimensi kuantitas indikator tingkat pencapaian target kerja di PT Perkebunan Nusantara IV Unit Usaha Balimbingan yang memperoleh nilai rata-rata 4,18 dengan kriteria baik, meskipun sudah berada di kriteria baik, namun angka ini merupakan nilai terendah dari keseluruhan dimensi kuantitas, hal ini disebabkan secara keseluruhan karyawan telah mampu mencapai target kerja

Selanjutnya pada dimensi kualitas terdapat indikator kerapian dalam menyelesaikan pekerjaan di PT Perkebunan Nusantara IV Unit Usaha Balimbingan memiliki rata-rata 4,07 dengan kriteria baik, hal ini disebabkan karyawan lebih menguasai bidang pekerjaannya.

Selanjutnya pada dimensi ketepatan waktu dengan indikator tenggang waktu dalam menyelesaikan tugas yang diberikan memiliki ratarata 3,98 dengan kriteria baik, hal ini disebabkan karyawan dalam menyelesaikan pekerjaan yang diberikan pimpinan selalu tenggang waktu. Cara mengatasi hal tersebut adalah pimpinan harus menindak tegas karyawan yang memanfaatkan waktu kerjanya untuk hal-hal diluar pekerjaannya sehingga membuat pekerjaan terkendala.

Pada dimensi kemampuan bekerjasama dengan indikator kerjasama pimpinan dengan karyawan atas tugas yang dibebankan memiliki ratarata 4,05 dengan kriteria baik, hal ini disebabkan karyawan dalam menyelesaikan pekerjaan yang diberikan pimpinan selalu tenggang waktu. Cara meningkatkannya adalah pimpinan dan karyawan harus selalu bekerjasama dalam menyelesaikan tugas yang dibebankan agar tujuan perusahaan dapat tercapai.

Pada dimensi kehadiran dengan indikator tingkat sistem jam kerja karyawan dalam kegiatankegiatan tertentu di PT Perkebunan Nusantara IV Unit Usaha Balimbingan memiliki rata-rata 4,27 dengan kriteria sangat baik, hal ini disebabkan karyawan selalu tepat waktu dalam kegiatan apapun.

Dari evaluasi kinerja karyawan di atas dapat diambil kesimpulan jika semua indikator sudah memiliki kriteria baik yang artinya kinerja karyawan sudah tercapai dengan baik. Namun untuk mengoptimalkan kinerja karyawan sebaiknya membina hubungan kerjasama yang baik antara sesama karyawan selain itu seorang pemimpin perusahaan harus memberikan motivasi kepada para karyawan agar dapat bekerja dengan prosedur yang ada pada perusahaan.

\section{KESIMPULAN DAN SARAN} 1.Kesimpulan

a. Hasil analisis regresi linier berganda diperoleh nilai $\hat{Y}=8,697+0,809 X_{1}+0,439 X_{2}$. Hal ini menunjukkan bahwa terdapat pengaruh positif antara variabel bebas motivasi $\left(\mathrm{X}_{1}\right)$ dan lingkungan kerja $\left(\mathrm{X}_{2}\right)$ terhadap kinerja karyawan (Y) pada PT Perkebunan Nusantara IV Unit Usaha Balimbingan

b. Hasil analisis koefisien korelasi diperoleh nilai $\mathrm{r}$ $=0,775$, yang artinya terdapat hubungan yang kuat dan positif antara motivasi dan lingkungan kerja dengan kinerja karyawan di PT Perkebunan Nusantara IV Unit Usaha Balimbingan. Kemudian diperoleh nilai koefisien determinasi ( $\mathrm{R}$ square $)=0,600$, artinya tinggi rendahnya kinerja karyawan (Y) di PT Perkebunan 
Nusantara IV Unit Usaha Balimbingan sebesar $60 \%$ dapat dijelaskan oleh motivasi (X1) dan lingkungan kerja (X2), sedangkan sisanya $40 \%$ dipengaruhi oleh faktor lain yang tidak dibahas dalam penelitian ini.

c. Hasil pengujian hipotesis secara simultan dengan uji $\mathrm{F}$, terdapat pengaruh yang positif dan signifikan antara motivasi dan lingkungan kerja terhadap kinerja karyawan, nilai $F_{\text {hitung }}$ sebesar 42,034 sedangkan $\mathrm{F}_{\text {tabel }}$ dengan $(0,05 ; 2$ vs 59$)$ sebesar 3,16 atau dengan taraf signifikansi 0,000 $<$ alpha 0,05 , maka $\mathrm{H}_{0}$ ditolak, artinya motivasi dan lingkungan kerja berpengaruh positif dan signifikan terhadap kinerja karyawan pada PT Perkebunan Nusantara IV Unit Usaha Balimbingan.

d. Hasil pengujian hipotesis secara parsial dengan uji t, terdapat pengaruh yang positif dan signifikan antara motivasi dan lingkungan kerja terhadap kinerja karyawan , diperoleh nilai $t_{\text {hitung }}$ pada variabel $X_{1}$ (motivasi) sebesar 4,309> dari $\mathrm{t}_{\text {tabel }}$ dengan $\mathrm{df}=\mathrm{n}-\mathrm{k}-1 \quad(59-2-1=56)$ sebesar 2,003 atau taraf signifikansi $0,000<$ alpha 0,05 , maka $\mathrm{H}_{0}$ ditolak, artinya motivasi berpengaruh positif dan signifikan terhadap kinerja karyawan pada PT Perkebunan Nusantara IV Unit Usaha Balimbingan secara parsial. Kemudian nilai $t_{\text {hitung }}$ pada variabel $\mathrm{X}_{2}$ (lingkungan kerja) sebesar 4,051 $>$ dari $\mathrm{t}_{\text {tabel }}$ dengan $\mathrm{df}=\mathrm{n}-\mathrm{k}-1 \quad(59-2-1=56)$ sebesar 2,003 atau taraf signifikan $0,000<$ alpha 0,05, maka $\mathrm{H}_{0}$ ditolak, artinya lingkungan kerja berpengaruh positif dan signifikan terhadap kinerja karyawan pada PT Perkebunan Nusantara IV Unit Usaha Balimbingan secara parsial.

\section{Saran}

a. Motivasi pada PT Perkebunan Nusantara IV Unit Usaha Balimbingan masih perlu ditingkatkan karena masih ada indikator yang belum optimal. Untuk itu pemimpin perusahaan sebaiknya meningkatkan motivasi bagi para karyawan yang berprestasi dengan cara memberi penghargaan atas hasil kerjanya agar karyawan lebih bersemangat dan dapat meningkatkan kualitas hasil kerja serta menjadi contoh untuk karyawan yang lain.

b. Untuk meningkatkan kinerja karyawan sebaiknya perusahaan lebih memperhatikan kondisi lingkungan kerja karyawan seperti melakukan penataan kembali penempatan meja dan kursi dengan cara membuat sekat pada setiap meja karyawan agar antara ruang kerja antar sesama karyawan memiliki batasan sehingga tidak terjadi kebisingan saat bekerja dan dapat meningkatkan produktivitas kerja karyawan.

c. Kinerja karyawan pada PT Perkebunan Nusantara IV Unit Usaha Balimbingan masih perlu ditingkatkan karena masih ada indikator yang belum optimal. Untuk mengoptimalkan kinerja karyawan sebaiknya membina hubungan kerjasama yang baik antara sesama karyawan selain itu seorang pemimpin perusahaan harus memberikan motivasi kepada para karyawan agar dapat bekerja dengan prosedur yang ada pada perusahaan agar tujuan perusahaan dapat tercapai dengan baik

d. Untuk mengoptimalkan hasil dari penelitian ini, maka diharapkan penelitian yang akan datang mengenai masalah yang sama dapat menambah variabel-variabel lain yang dipandang relevan dan lebih mendalam lagi pembahasannya, misalnya dengan membedakan tingkat kinerja karyawan pada tiap bagian atau departemen. Selain itu apabila memakai kuesioner sebaiknya dalam pengisiannya dipandu ditambah dengan wawancara langsung tiap karyawan yang teliti, sehingga kuesioner nantinya dapat terisi dengan baik.

\section{E. DAFTAR PUSTAKA}

Griffin, Ricky W. 2004. Manajemen. Cetakan keempat. Jakarta: Penerbit Erlangga.

Handoko, T. Hani. 2002. Manajemen. Yogyakarta: BPEE.

Luthans, Fred. 2006. Perilaku Organisasi. Yogyakarta: Penerbit Andi.

Mathis, Robert dan John, H. Jackson. 2006. Human Resourch Management. Jakarta: Salemba Empat.

Mangkunegara, A. Prabu, 2005. Evaluasi Kinerja. Bandung: Refika Aditama.

Mondy, R. Wayne. 2008. Manajemen Sumber Daya Manusia. Jakarta: Erlangga

Nitisemito, Alex. 2000. Manajemen Personalia. Jakarta: Ghalia Indonesia

Rivai, Veithzal. 2004. Manajemen Sumber Daya Manusia Untuk Perusahaan dari Teori ke Pabrik, Jakarta: PT. Raja Grafindo Persada.

Robbins, Stephen P. dan Timothy A. Judge. 2006. Perilaku Organisasi. Edisi 12, Jakarta: Salemba Empat.

Sedarmayanti, 2001.Manajemen Sumber Daya Manusia. Jakarta: Penerbit Refika Aditama.

.........,2011. Manajemen Sumber Daya

Manusia. Jakarta: Penerbit Refika Aditama.

Wibowo, 2011. Manajemen Kinerja, Edisi Ketiga, Cetakan Kelima, Jakarta: Rajawali Pers 